Tersedia online: http://journal.stainkudus.ac.id/index.php/jbe

\title{
Kombinasi Bioremediasi Apu-Apu Dan Material Nano-Zeolit Terhadap Air Limbah Sungai Gelis Kota Kudus
}

\author{
Izzatin Aulia Rahmah ${ }^{1}$, Aulia Salsabila ${ }^{2}$, Shilfiya Amalina ${ }^{3}$, Laily Istiqomah ${ }^{4}$, Ahmad Edi \\ Darmawan $^{5}$ \\ (1), (2), (3), (4), (5) SMA NU Al Ma'ruf Kudus, Jawa Tengah, Indonesia \\ Jl. AKBP R. Agil Kusumadya No.2 Kudus 59348 \\ izzatinaulia1117@gmail.com
}

\begin{abstract}
ABSTRAK
Sungai Gelis merupakan sungai terbesar yang membelah di tengah Kota Kudus. Kondisi sungai Gelis saat ini bisa dibilang sangat memprihatinkan karena air yang berwarna hitam dan memiliki bau tak sedap. Adanya beragam aktivitas manusia di sekitar Sungai Gelis sangat berdampak pada ekosistem sungai dan manusia itu sendiri. Oleh karena itu, diperlukan upaya solutif dalam mengatasi masalah ini guna terciptanya perairan yang bersih dan bebas polutan. Penelitian ini bertujuan untuk memperbaiki kualitas air sungai di Sungai Gelis menggunakan kombinasi bioremediasi apu-apu dan material nano-zeolit. Penelitian ini menggunakan Rancangan Acak Lengkap yang terdiri atas 4 perlakuan dengan 3 kali ulangan. Perlakuan dalam penelitian ini, meliputi P0: Kontrol (tanpa apu - apu dan nano zeolit), P1: Air sungai gelis diremedisi dengan tanaman apu - apu, P2: Air sungai gelis diremedisi dengan nano zeolit, dan P3: Air sungai gelis diremedisi dengan tanaman apu - apu dan nano zeolit. Pengujian air limbah Sungai Gelis dilakukan secara fisika, kimia, dan biologi. Hasil menunjukan bahwa kombinasi apu-apu dan nanozeolit didapatkan kualitas air yang jernih, tidak berbau, Ph menjadi normal, dan tidak ada mikroorganisme.
\end{abstract}

Kata kunci : Sungai gelis, Apu-apu, dan Nanozeolit.

\begin{abstract}
Gelis River is the largest river that divides in the middle of the Holy City. The current condition of the Gelis river is very alarming because the water is black and has an unpleasant odor. The variety of human activities around the Gelis River greatly affects the river and human ecosystems themselves. Therefore, a solution is needed in overcoming this problem in order to create clean and pollutant-free waters. This study aims to improve the quality of river water in Sungai Gelis using a combination of apu-ape bioremediation and nano-zeolite
\end{abstract}


material. This study uses a completely randomized design consisting of 4 treatments with 3 replications. The treatment in this study included P0: Control (without apu - apu and nano zeolite), P1: Gelis river water was reheated with apu - apu plant, P2: Gelis river water was treated with nano zeolite, and P3: Gelis river water was treated with plants apu - apu and nano zeolite. Testing of Sungai Gelis wastewater is carried out in physics, chemistry and biology. The results showed that the combination of apu-apu and nanozeolite obtained clear water quality, odorless, $\mathrm{pH}$ became normal, and no microorganisms.

Keywords: River gelis, Apu-apu, and Nanozeolite.

\section{PENDAHULUAN}

Sungai Gelis merupakan sungai terbesar yang membelah di tengah kota Kudus. Sungai Gelis mempunyai peranan yang sangat penting bagi masyarakat kota karena pada sungai ini terdapat 2 buah bendung yang merupakan pengambilan dari irigasi, masing-masing adalah Bendung Kedunggumpit dan Bendung ploso (Peraturan Bupati Kudus No.41 Tahun 2012). Kondisi Sungai Gelissaat ini bisa dibilang sangat memprihatinkan. Adanya beragam aktivitas manusia di sekitar Sungai Gelis sangat berdampak pada menurunnya kualitas air sungai dari hulu sampai ke hilir. Ketika Sungai Gelis tercemar maka akan sangat berdampak pada ekosistem sungai dan manusia itu sendiri.

Segala bentuk pencemaran tidak mengenal batas administratif begitu juga dengan pencemaran air sungai karena sungai yang mengalir biasanya melintasi beberapa wilayah kabupaten atau bahkan lintas provinsi, sehingga walaupun di suatu daerah tidak terdapat suatu aktifitas yang menyebabkan pencemaran air tetap badan airnya berpotensi untuk tercemar. Pencemaran air di banyak wilayah, telah mengakibatkan terjadinya krisis air bersih, lemahnya pengawasan oleh instansi terkait menjadikan problem pencemaran air menjadi hal yang kronis yang makin lama makin parah, walaupun perangkat untuk melakukan pengawasan dari suatu kegiatan telah ada seperti adanya dokumen AMDAL (Pahruddin, 2017).

Selain itu, aktivitas industri, pemukiman, pertanian, serta pertambangan di bagian hulu pada umumnya dapat menimbulkan masalah-masalah seperti pencemaran air, menurunnya kualitas sumber daya alam, lahan kritis, gangguan ksesehatan, penurunan potensi sumber daya alam hayati, bencana alam, serta 
sedimentasi di bagian hilir (Suparjo, 2009). Sehingga secara kulitas mengalami penurunan, dan secara kuantitas tidak dapat memenuhi kebutuhan yang terus meningkat. Hanisa dkk, (2017) menyatakan bahwa kualitas Air Sungai Gelis berdasarkan metode Indeks Kualitas Air-National Sanitation's Foundation (IKANSF) meliputi 9 parameter mulai dari parameter Fisika (Suhu, Temeperatur, Kekeruhan), Kimia (pH, DO, BOD, Fosfat, Nitrat), dan Biologi (Fecal coliform) berstatus buruk. Kualitas air Sungai Gelis menunjukan penaikan dan penurunan kualitasnya dengan nilai IKA-NSF antara 46 sampai dengan 54.

Berdasarkan permasalahan tersebut, maka diperlukan upaya solutif dalam mengatasi masalah ini guna terciptanya perairan yang bersih dan bebas polutan. Salah satu upaya konservasi untuk mengatasi Sungai Gelis yang tercemar menggunakan bioremediasi tanaman apu-apu berbasis nanozeolit. Tanaman apuapu memiliki beberapa potensi dalam menurunkan kadar pencemar air limbah yang memiliki kadar organik tinggi. Sementara penggunaan nanozeolit sendiri dapat menyerap logam berat. Upaya konservasi lingkungan dengan kedua bahan ini diharapkan mampu mengatasi permasalahan pencemaran Sungai Gelis sehingga kualitas air menjadi lebih baik sehingga ekosistem sungai terjaga.

Hasil penelitian Wirawan, et al. (2010) didapatkan pengaruh Pistia stratiotes $L$. dalam pengolahan limbah cair domestik menunjukkan adanya peningkatan nilai BOD maksimal sebesar 45,35\%, penurunan nilai COD maksimal sebesar $65,06 \%$, penurunan nilai TSS maksimal sebesar $19,99 \%$, nilai pH maksimum sebesar 8,50, dan penurunan nilai minyak dan lemak maksimum sebesar 37,10\%. Sementara Motsi et al. (2009) menyatakan bahwa zeolit alam sebagai adsorben tanpa modifikasi kimia dapat menyerap logam $\mathrm{Fe}^{2^{+}}, \mathrm{Cu}^{2^{+}}, \mathrm{Zn}^{2^{+}}$, dan $\mathrm{Mn}^{2^{+}}$dalam air asam tambang, dilakukan dalam kondisi batch.

\section{METODE PENELITIAN}

Percobaan dilakukan selama 15 hari mulai dari tanggal 5 September hingga 20September 2018. Percobaaan dilakukan eksperimental di Laboratorium Biofis SMA NU AL Ma'ruf. Pada percobaan ini untuk mengetahui efektivitas serapan pencemar oleh tanaman apu-apu dan zeolit. 


\section{Alat dan Bahan}

Alat yang digunakan dalam penelitian yaitu Gelas beker, Aqua botol, Cutter, dan $\mathrm{Ph}$ indicator. Sementara bahan yang digunakan dalam penelitian ini meliputi Air limbah sungai Gelis, Tanaman apu - apu, dan Nanozeolit

\section{Rancangan Penelitian}

Rancangan percobaan terdiri dari 4 percobaan 3 ulangan yaitu P0: Kontrol (tanpa apu - apu dan nano zeolit), P1: Air sungai gelis diremedisi dengan tanaman apu - apu, P2: Air sungai gelis diremedisi dengan nano zeolit, dan P3: Air sungai gelis diremedisi dengan tanaman apu - apu dan nano zeolit.

\section{Metode Uji Kualitas Air}

Kualitas air sebelum dan setelah dapat diuji untuk mengetahui pengaruh remediasi apu-apu dan nanozeolit terhadap air limbah sungai Gelis guna peningkatan kualitas air. Kualitas air yang diuji meliputi uji fisik, kimia dan biologi yang dilakukan secara sederhana.

\section{Uji Fisika}

Uji Fisika mengacu pada metode Kusnaedi (2010) dengan modifikasi seperlunya.Uji Fisik air meliputi uji organoleptik dengan mengamati kekeruhan, warna, baudan rasa air sebelum dan sesudah menggunakan apu-apu dan nanozeolit. Selain itu juga dilakukan uji fisika sederhana menggunakan metode tuang, yaitu dengan menuangkan air yang akan diuji ke dalam gelas ukur lalu diberi air standar dan diamati reaksi yang terjadi. Uji ini dilakukan untuk mengetahui tingkat pencemaran.

\section{Uji Kimia}

Uji kimia dilakukan secara sederhana mengacu pada metode Kusnaedi (2010), yaitu dengan menganalisis kualitas air yang telah dicampur teh. Apabila terdapat perubahan warna, lender dan lapisan minyak pada permukaan air disimpulkan kulitas air tidak dijadikan bahan baku air minum.

\section{Uji Biologi}

Analisa kualitas air secara biologi bertujuan untuk mengetahui ada atau tidaknya bakteri dalam air. Dengan mata telanjang tidak dapat diketahui keberadan mikroorganisme. Namun ini bisa dilakukan dengan uji sederhana yaitu 
dengan cara mendiamkan air uji selama beberapa hari, paling tidak selama 5 hari (Kusnaedi, 2010).

\section{Analisa dan Evaluasi}

Pada tahap ini dilakukan analisa dan evaluasi dari serangkaian penelitian yang telah dilakukan. Parameter yang ditinjau adalah kombinasi tanaman apu-apu dan nanozeolit untuk bioremidiasi air sungai gelis yang tercemar dan kualitas air yang dihasilkan.

\section{HASIL DAN PEMBAHASAN}

Hasil pengamatan kondisi Sungai Gelis yang berada di area pemukiman Desa Ploso Kecamatan Jati Kudus menunjukan bahwa keadaan sungai sangat tercemar. Indikator pencemaran berdasarkan pada warna air yang sangat gelap dan bau tidak sedap. Selain itu banyak tumpukan sampah mengakibatkan kondisi Sungai Gelis sangat parah dan tidak enak untuk dipandang.

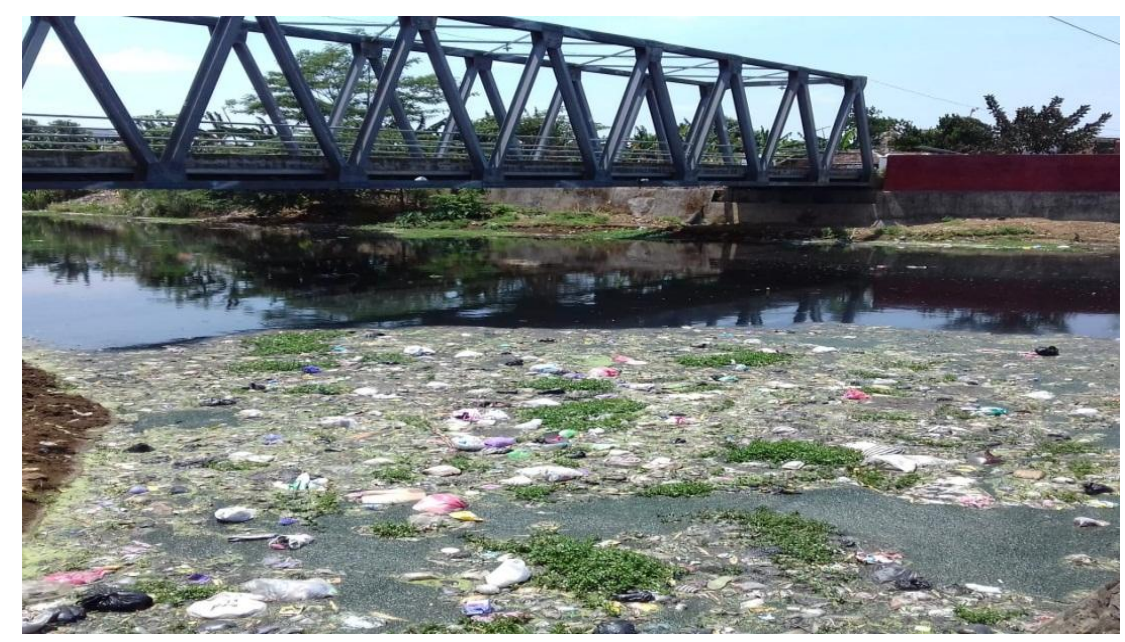

Gambar 1. Kondisi Sungai Gelis (Dokumentasi Pribadi, 2018)

Hasil uji kualitas air limbah Sungai Gelis yang telah diremediasi menggunakan apu-apu dan zeolit berdasarkan uji fisika, kimia, dan biologi didapatkan hasil berikut.

\section{Uji Fisika}

Uji fisika sederhana yang telah dilakukan meliputi uji organoleptik secara langsung melalui panca indera.Parameter yang diuji yaitu kekeruhan, warna, 
aroma, dan PH. Berikut merupakan hasil uji fisika sebelum dan setelah pemberian perlakuan.

Tabel 1. Hasil pengamatan uji fisika sungai Gelis tanpa perlakuan

\begin{tabular}{cccccccc}
\hline \multicolumn{2}{c}{ Kekeruhan } & \multicolumn{2}{c}{ Warna } & \multicolumn{2}{c}{ Aroma } & \multicolumn{2}{c}{ PH } \\
\hline $\begin{array}{c}\text { Hari } \\
\text { ke-1 }\end{array}$ & $\begin{array}{c}\text { Hari } \\
\text { ke-7 }\end{array}$ & $\begin{array}{c}\text { Hari ke- } \\
1\end{array}$ & Hari ke-7 & Hari ke-1 & Hari ke-7 & $\begin{array}{c}\text { Hari } \\
\text { ke-1 }\end{array}$ & $\begin{array}{c}\text { Hari } \\
\text { ke-7 }\end{array}$ \\
\hline Keruh & Keruh & Hitam & Hitam & $\begin{array}{c}\text { Bau } \\
\text { menyengat }\end{array}$ & $\begin{array}{c}\text { Bau } \\
\text { Menyengat }\end{array}$ & 6 & 6 \\
\hline
\end{tabular}

Hasil penelitian pada perlakuan kontrol sungai gelis yang tercemar berdasarkan parameter uji fisika yang meliputi kekeruhan, warna, aroma, dan ph selama 7 hari. Tingkat kekeruhannya yaitu masih keruh. Warna air yang sangat hitam.Aroma air sungainya juga mempunyai bau menyengat dan ph airnya 6 .

Tabel 2. Hasil pengamatan uji fisika sungai Gelis setelah diremediasi apu-apu

\begin{tabular}{|c|c|c|c|c|c|c|c|}
\hline \multicolumn{2}{|c|}{ Kekeruhan } & \multicolumn{2}{|c|}{ Warna } & \multicolumn{2}{|c|}{ Aroma } & \multicolumn{2}{|c|}{ PH } \\
\hline $\begin{array}{l}\text { Hari } \\
\text { ke-1 }\end{array}$ & $\begin{array}{l}\text { Hari } \\
\text { ke-7 }\end{array}$ & Hari ke-1 & Hari ke-7 & Hari ke-1 & Hari ke-7 & $\begin{array}{c}\text { Hari ke- } \\
1\end{array}$ & $\begin{array}{l}\text { Hari } \\
\text { ke-7 }\end{array}$ \\
\hline Keruh & Jernih & Hitam & $\begin{array}{c}\text { Tidak } \\
\text { berwarna }\end{array}$ & $\begin{array}{c}\text { Bau } \\
\text { menyengat }\end{array}$ & Bau amis & 6 & 6 \\
\hline
\end{tabular}

Hasil penelitian pemberian tanaman apu-apu terhadap sungai gelis yang tercemar berdasarkan parameter uji fisika yang meliputi kekeruhan, warna, aroma, dan ph selama 7 hari. Tingkat kekeruhan air yang semula keruh menjadi jernih. Warna air yang semula hitam menjadi tidak berwarna. Aroma air sungainya juga semula mempunyai bau menyengat menjadi bahu amis dan ph airnya 6 . 
Tabel 3. Hasil pengamatan uji fisika sungai Gelis setelah diremediasi nano zeolit

\begin{tabular}{cccccccc}
\hline \multicolumn{2}{c}{ Kekeruhan } & \multicolumn{2}{c}{ Warna } & Aroma & \multicolumn{2}{c}{ PH } \\
\hline $\begin{array}{cccccc}\text { Hari } \\
\text { ke-1 }\end{array}$ & $\begin{array}{c}\text { Hari } \\
\text { ke-7 }\end{array}$ & Hari ke-1 & Hari ke-7 & Hari ke-1 & Hari ke-7 & Hari ke- & Hari \\
\hline \multirow{2}{*}{ Keruh } & Jernih & Hitam & $\begin{array}{c}\text { Tidak } \\
\text { berwarna }\end{array}$ & $\begin{array}{c}\text { Bau } \\
\text { menyengat }\end{array}$ & Tidak Bau & 6 & 7 \\
\hline
\end{tabular}

Hasil penelitian pemberian nanozelit terhadap sungai gelis yang tercemar berdasarkan parameter uji fisika yang meliputi kekeruhan, warna, aroma, dan ph selama 7 hari. Tingkat kekeruhan air yang semula keruh menjadi jernih. Warna air yang semula hitam menjadi tidak berwarna. Aroma air sungainya juga mempun yai bau menyengat menjadi tidak bau dan ph airnya yang semula 6 menjadi normal (ph 7).

Tabel 4. Hasil pengamatan uji fisika sungai Gelis setelah diremediasi apu-apu

\begin{tabular}{|c|c|c|c|c|c|c|c|}
\hline \multicolumn{2}{|c|}{ Kekeruhan } & \multicolumn{2}{|c|}{ Warna } & \multicolumn{2}{|c|}{ Aroma } & \multicolumn{2}{|c|}{$\mathbf{P H}$} \\
\hline $\begin{array}{l}\text { Hari } \\
\text { ke-1 }\end{array}$ & $\begin{array}{c}\text { Hari ke- } \\
7\end{array}$ & $\begin{array}{c}\text { Hari ke- } \\
1\end{array}$ & Hari ke-7 & Hari ke-1 & Hari ke-7 & $\begin{array}{c}\text { Hari ke- } \\
1\end{array}$ & $\begin{array}{l}\text { Hari } \\
\text { ke-7 }\end{array}$ \\
\hline Keruh & Jernih & Hitam & $\begin{array}{c}\text { Tidak } \\
\text { berwarna }\end{array}$ & $\begin{array}{c}\text { Bau } \\
\text { menyengat }\end{array}$ & Tidak Bau & 6 & 7 \\
\hline
\end{tabular}

Hasil penelitian pemberian apu-apu dan nanozelit terhadap sungai gelis yang tercemar berdasarkan parameter uji fisika yang meliputi kekeruhan, warna, aroma, dan ph selama 7 hari. Tingkat kekeruhan air yang semula keruh menjadi jernih. Warna air yang semula hitam menjadi tidak berwarna. Aroma air sungainya juga mempun yai bau menyengat menjadi tidak bau dan ph airnya yang semula 6 menjadi normal (ph 7).

Berdasarkan hasil uji fisika terhadap air sungai gelis yang tercemar limbah menunjukan kombinasi apu-apu dan nanzeolit menghasilkan air yang semula 
tercemar dan berbau menjadi jernih dan tidak berbau. Sementara PH air menjadi normal yang mengindikasikan bahwa sumber air bisa digunakan kembali. Hasil ini sesuai dengan kualitas air menurut Hidayat (2011) yang dimana indikatior air bersih yaitu air tidak berwarna, tidak berbau, dan ph antara 6-8,5.

Tabel 5. Tabel Kualitas Air (Hidayat, 2011)

\begin{tabular}{|c|c|c|c|}
\hline \multirow{2}{*}{ Parameter } & \multicolumn{2}{|c|}{ Sampel Air } & \multirow{2}{*}{$\begin{array}{c}\text { Standar } \\
\text { Konsumsi }\end{array}$} \\
\hline & Air Laut & Air Tawar & \\
\hline Warna & $\begin{array}{l}\text { Tidak } \\
\text { berwarna }\end{array}$ & $\begin{array}{l}\text { Tidak } \\
\text { berwarna }\end{array}$ & $\begin{array}{l}\text { Tidak } \\
\text { berwarna }\end{array}$ \\
\hline Bau & $\begin{array}{l}\text { Tidak } \\
\text { berbau }\end{array}$ & $\begin{array}{l}\text { Tidak } \\
\text { berbau }\end{array}$ & $\begin{array}{l}\text { Tidak } \\
\text { berbau }\end{array}$ \\
\hline Salinitas & 33 & 0 & 0,5 \\
\hline PH & 8 & 6,8 & $6-8,5$ \\
\hline
\end{tabular}

\section{Uji Kimia}

Uji kimia secara sederhana yang dilakukan meliputi uji organoleptik secara langsung melalui panca indra. Parameter yang di uji yaitu menganalisis kualitas air yang telah dicampur teh. Apabila terdapat perubahan warna, lendir dan lapisan minyak pada permukaan air disimpulkan kulitas air tidak dijadikan bahan baku air minum.
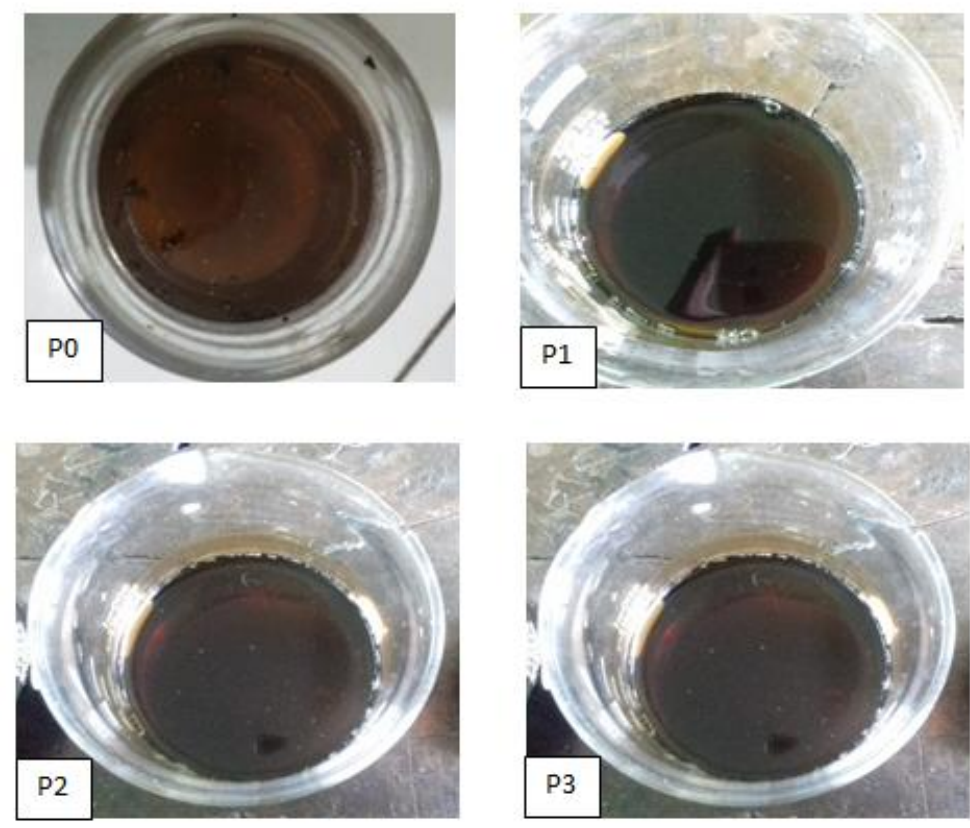

Gambar 2. Hasil Uji Kimia (Dokumentasi Pribadi, 2018) 
Keterangan $=$ P0: Kontrol, P1: Air Sungai Gelis tercemar diremediasi dengan apu-apu, P2: Air Sungai Gelis tercemar diremediasi dengan apuapu, P3: Air Sungai Gelis tercemar diremediasi dengan apu-apu dan nano-zeolit.

Hasil uji kimia sederhana telah dilakukan dan didapatkan hasil bahwa air sampel yang diuji tidak layak untuk digunakan. Setelah dilakukan pengujian selama 24 jam, terdapat gelembung-gelembung kecil yang merupakan aktivitas mikroba serta terdapat bintik-bintik putih pada air sampel tanpa perlakuan. Sementara tiga sampel hasil perlakuan (P1, P2, dan P3) menunjukkan tidak adanya lendir dan perubahan warna sehingga membuktikan bahwa kualitas air baik untuk digunakan.

\section{Uji Biologi}

Uji biologi secara sederhana dilakukan dengan cara mendiamkan air uji selama beberapa hari, paling tidak selama 5 hari. Parameter uji yaitu mengamati organisme yang terdapat didalam air tersebut melalui mikroskop. Apabila ada bakteri didalam air maka air tersebut tidak layak untuk digunakan.
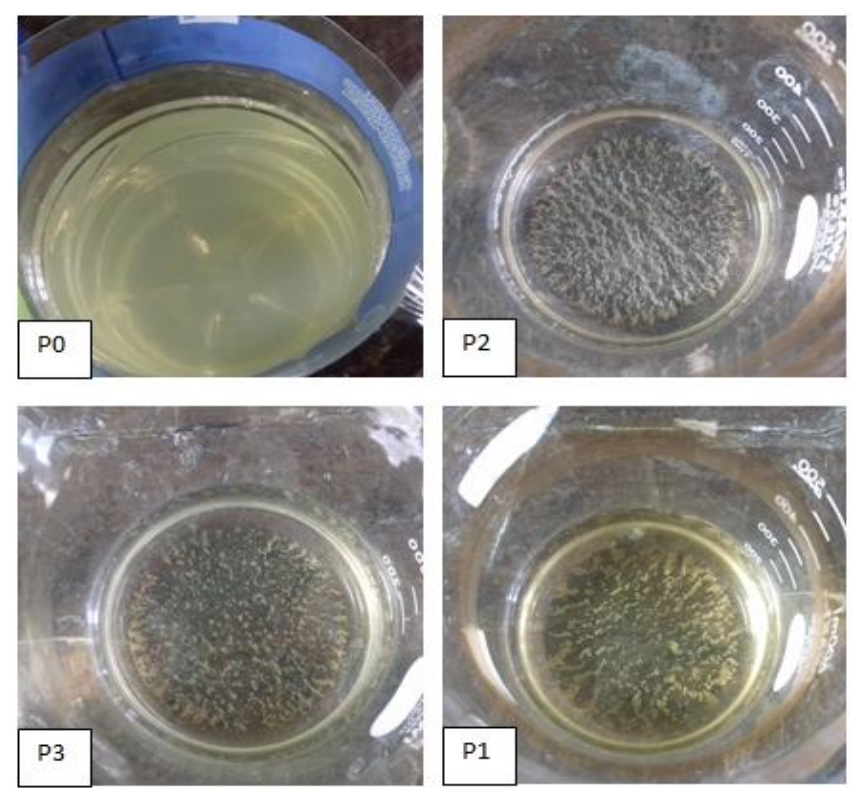

Gambar 3. Hasil Uji Biologi (Dokumentasi pribadi, 2018) 
Keterangan $=$ P0: Kontrol, P1: Air Sungai Gelis tercemar diremediasi dengan apu-apu, P2: Air Sungai Gelis tercemar diremediasi dengan apuapu, P3: Air Sungai Gelis tercemar diremediasi dengan apu-apu dan nano-zeolit.

Hasil uji biologi sederhana telah dilakukan dan didapatkan hasil bahwa air sampel yang diuji tidak layak untuk digunakan. Setelah dilakukan pengujian selama 5 hari, terdapat mikroorganisme yang ada dalam air sungai gelis tanpa perlakuan. Sementara tiga sampel hasil perlakuan (P1, P2, dan P3) menunjukan bahwa air sampel yang diuji layak untuk digunakan. Setelah melakukan pengujian kurang lebih selama 5 hari, tidak ditemukannya mikroorganisme dalam air sampel tersebut.

Dari hasil uji fisika, kimia, dan biologi menunjukan bahwa tanaman apu apu dan nanozeolit dapat meremediasi limbah yang ada di sungai Gelis. Hal ini karena Apu - apu merupakan tanaman yang memiliki potensi dalam menurunkan kadar pencemar air limbah yang memiliki kadar organik tinggi. Kemampuan mencengkeram lumpur dengan berkas -berkas akarnya kadang dimanfaatkan sebagai pembersih sungai yang sangat kotor. Dalam industri tanaman ini biasanya digunakan sebagai penyerap unsur-unsur toksis pada air limbah. Tanaman apuapu mempunyai keunggulan dibandingkan dengan tumbuhan lain seperti daya berkecambah yang tinggi, pertumbuhan cepat, tingkat absorbsi atau penyerapan unsur hara dan air yang besar, mudah ditemukan dan daya adapsi yang tinggi terhadap iklim (Fachrurozi et al, 2010).

Hasil penelitian Wirawan, et al. (2010) didapatkan pengaruh Pistiastratiotes L. dalam pengolahan limbah cair domestik menunjukkan adanya peningkatan nilai BOD maksimal sebesar 45,35\%, penurunan nilai COD maksimal sebesar 65,06\%, penurunan nilai TSS maksimal sebesar 19,99\%, nilai $\mathrm{pH}$ maksimum sebesar 8,50, dan penurunan nilai minyak dan lemak maksimum sebesar 37,10\%. Pada penelitian Ulfin dan Widya (2005) penyerapan kromium dengan kayu apu dapat mereduksi konsentrasi kromium dengan efisiensi 89,98\%.

Zeolit merupakan suatu kelompok mineral yang dihasilkan dari proses hidrotermal pada batuan beku basa. Mineral ini biasanya dijumpai mengisi celahcelah ataupun rekahan dari batuan tersebut.Selain itu zeolit juga merupakan 
endapan dari aktivitas volkanik yang banyak mengandung unsur silika.Karena sifat-sifat yang dimiliki oleh zeolit, maka mineral ini dapat dimanfaatkan sebagai bahan untuk membantu pengolahan limbah.

Zeolit sendiri juga dimanfaatkan sebagai media pertukaran ion untuk ion logam dan merupakan sorben yang efektif untuk penyisihan ion logam. Beberapa logam berat dari limbah electroplating dan air asam tambang yang dapat disisihkan menggunakan zeolit yaitu $\mathrm{Cr}$ (III), $\mathrm{Ni}$ (II), $\mathrm{Zn}$ (II), $\mathrm{Cu}$ (II), dan $\mathrm{Cd}$ (II) (Tyagi et al., 2012). Menurut Yanto (2011) telah melakukan studi tentang penggunaan zeolit sebagai media penyaring pada pengolahan air limbah domestik. Melalui metode tersebut didapatkan hasil penurunan E coli 99,9\% dan BOD serta DO sebesar $71 \%$ dan $66 \%$ dalam air limbah domestik.

\section{KESIMPULAN}

Kondisi Sungai Gelis tercemar disebabkan karena adanya limbah domestik, limbah pertanian, dan limbah industri. Hal tersebut menyebabkan warna air menjadi sangat gelap dan menimbulkan bau tak sedap. Bioremediasi air limbah Sungai Gelis dilakukan dengan cara melakukan pengujian secara fisika, kimia, dan biologi dalam waktu 7 hari. Hasil menunjukan bahwa kombinasi apu-apu dan nanozeolit didapatkan kualitas air yang jernih, tidak berbau, dan Ph menjadi normal. Berdasarkan pengujian, tanaman apu-apu dan teknologi nanozeolit dapat memulihkan kondisi air sungai yang sudah tercemar.

\section{DAFTAR PUSTAKA}

Anonim. (2012). Peraturan Bupati Kudus No.41 Tahun 2012 tentang Program Indikatif Kabupaten Kudus Tahun 2014.

Effendi, H. (2003). Telaah Kualitas Air: Bagi Pengelolaan Sumber Daya dan Lingkungan Perairan. Kanisius, Yogyakarta.

Fachrurozi, M., B.U. Listiatie dan D. Suryani. (2010). Pengaruh Variasi Biomassa Pistia stratiotes L. terhadap Penurunan Kadar BOD, COD dan TSS Limbah Cair Tahu di Dusun Klero Sleman Yogyakarta. Fakultas Kesehatan Masayarakat Universitas Ahmad Dahlan, Yogyakarta. ISSN : 1978-0575. 
Hanisa, Estu. Winardi Dwi Nugraha, dan Anik Sarminingsih. (2017). Penentuan Status Mutu Air Sungai BerdasarkanMetode Indekskualitas Air-National SanitationFoundation (Ika-Nsf) SebagaiPengendalian Kualitas Lingkungan(Studi Kasus : Sungai Gelis, Kabupaten Kudus, Jawa Tengah). Jurnal Teknik Lingkungan, Vol. 6, No. 1

Hidayat,B. (2011). Screening Tumbuhan Air Hiperakumulator. Disertasi Program Doctor FakultasPertanianUniversitas Sumatera Utara. Sumatera Utara.

Hermawati, E., Wiryanto., and Solichatun. (2005). Fitoremediasi Limbah Detergen Menggunakan Kayu Apu (Pistia stratiotes L.) dan Genjer (Limnocharis flava L). Jurusan Biologi FMIPA Universitas Sebelas Maret (UNS) Surakarta. Vol 7 No 2: 115-124

Khan, M, A. Yasar. (2013). Percentage Uptake Of Heavy Metals Of Different Macrophytes In Stagnant And Flowing Textile Effluent. The Journal of Animal \& Plant Sciences, 23(6):1709-1713

Kusnaedi. (2010). Mengolah Air Kotor untuk Air Minum. Jakarta: Penebar Swadaya

Motsi, T., Rowson, N. A., and Simmons, M. J. H. (2009). Adsorption of heavy metals from acid mine drainage by natural zeolite. International Journal of Mineral Processing. 92: 42-48.

Nabila Y, Winardi Dwi Nugraha, dan Anik Sarminingsih. (2017). Analisis Penentuan Daya Dukung Lingkungan Di Daerah Aliran Sungai (Studi Kasus: Sungai Gelis, Kabupaten Kudus). Jurnal Teknik Lingkungan, Vol. 6, No. 1

Pahruddin, Muhammad. (2017). Risiko Pajanan Logam Berat Pada Air Sungai. Jurnal Kesehatan Lingkungan Vol. 14 No. 2

Saputra, R. (2006). Pemanfaatan Zeolit Sintetis Sebagai Alternatif Pengolahan Limbah Industri.

Tyagi et al. (2012). "Nanomaterials Use in Wastewater Treatment", International Conference on Nanotechnology and Chemical Engineering (ICNCS'2012)Bangkok (Thailand).

Ulfin, I. Amirudin, P. Zainuddin, M. (2000). Pengaruh Logam Berat Pb pada Penyerapan Logam Berat Cd dalam Larutan oleh Kayu Apu (Pistia stratiotes L.). Prosiding SENAKI II, Kimia-FMIPA, ITS, Surabaya

Ugya, A. Y. (2015). The Use Of P.stratiotes To Remove Some Heavy Metals From Romi Stream: A Case Study Of Kaduna Refinery And Petrochemical Company Polluted Stream. IOSR Journal of Environmental Science, Toxicology and Food Technology(IOSR-JESTFT), 9 (1) 
Wirawan, et al. (2010). Pengolahan Limbah Cair DomestikMenggunakantanaman Kayu Apu (Pistia Stratiotes L.)Dengan Teknik Tanam Hidroponik Sistem Dft(Deepflowtechnique). Jurnal Sumberdaya Alam dan Lingkungan

Yanto, (2011), Penggunaan Zeolit sebagai Media Penyaring pada Pengolahan Air Limbah Domestik, Universitas Jendral Soedirman, Purbalingga 
